\title{
New Definition and Classification of Chinese Prepositions from the Perspective of English Structural Transformation Grammar
}

\author{
Zhao Zhao \\ Hohhot Vocational College, Hohhot, Inner Mongolia, 010051, China
}

Keywords: Prepositions, Structural transformation grammar, Definition, Prepositions classification, Word-mediated predicate.

\begin{abstract}
Since the publication of Ma Shi Wen Tong, Chinese preposition research has achieved a great success. However, the definition of prepositions, especially their differences from verbs and conjunctions, has varied from one genre to another, leading inconvenience to many Chinese learners. This paper redefines and classifies the prepositions according to the structure transformation grammar, and newly divides a kind of word-mediated predicate to solve the problem of the definition of the prepositions and the difference between the prepositions and the verbs and conjunctions for a long time after the controversy in the syntactic circles.
\end{abstract}

\section{Introduction}

Prepositions are a very important and quite complex part of speech in Chinese. Compared with English, Chinese has no developed morphological changes. As the main means of expressing grammatical relations and grammatical categories, the prepositions in Chinese play a very important role. However, due to the close relationship between Chinese prepositions and verbs, the definition of the part of speech in Chinese grammar circles has been confused.

Structural Transformation Grammar (Chen Guohua, 2007) argues that if we regard language as a system, syntactically speaking, this system can be said to consist of two subsystems, one is the basic structural system and the other is the transformation system. Each of the constructions of a language is composed of at least two components. The two components are in parallel with each other or with each other in the central language and the dependent language, or the relation of the two languages is different from each other. The two or more components that form the predicate relationship may be the subject and the predicate, the predicate and the object, the subject predicate object, the subject predicate object, the predicate complement, the predicate object complement, and the main verb and object complement, etc..

According to the structural transformation grammar, the traditional grammar ignores the first law of the classification of the prepositions, that is to say, whether the preposition can serve as the predicate or the presumption. Leaving this foundation, any attempt to find a single definitive categorization of the inhomogeneous definition of object is futile.

This paper focuses on four aspects: the deficiency of traditional Chinese preposition research, the new definition of preposition by structural transformation grammar, the preposition classification under new definition and the newly classified part-predicate.

\section{The Inadequacy of Traditional Preposition Research}

\subsection{Illogical Definition of Part of Speech}

As a symbol of the birth of Chinese grammar, "Ma Shi Wen Tong" began a study of prepositions in the sense of true grammar. Ma Shi Wen Tong divides ancient Chinese words into two categories: real words and imaginary words. Preposition is one of the imaginary words. "Ma Shi Wen Tong" thinks: "Where the imaginary word is used to connect with the real meaning of the righteous, said the Preposition, and it is actually the introduction of the real word." Ma Shi Wen Tong established the 
Chinese Word class-Preposition, and explain the role of preposition in the sentence structure Introduction. Since then, most of the scholars' understanding of prepositions has been influenced by the viewpoint of Ma Shi Wen Tong and achieved some results.

Without Preposition

Lv Shuxiang (1984), pointed out that one does not stand prepositions, as a verb to attach with a verb. Wang Li (1985) combined "于(yú)、以(yǐ)、与(yǔ) 、同(tóng)" and other conjunctions and referred to as "conjunctions," while "在(zài) 、往(wăng)、朝(zhāo)、从(cóng)、把(bă)、被 (bèi)" as auxiliary which does not exist in the word system of these two books.

Both Verbs and Prepositions

Li Jinxi (1924) argues that when they are used alone in predicates, they are verbs, that is, they are both verbs and prepositions. Guo Yizhou (1984) pointed out that when they carry modifiers or supplements as nouns and pronouns, they are prepositions, and when they are used alone as predicates, they are verbs, that is, all words that can be both prepositions and verbs in both types.

c. Preposition is a kind of function words, which come from the verb

Zhang Zhigong (1953) claimed that prepositions belong to function words. Liu Yuehua (2001) proposed preposition is a kind of function words. Most prepositions are derived from the verb.

Thus, according to the definition of prepositions in the traditional grammar, in the end which type of prepositions belong to, what words can be called prepositions made us fall into the deadlock of the word indefinable class.

\subsection{Fuzzy Definition of Grammatical Function}

Li Jinxi (1924) said that "prepositions are used to introduce nouns or pronouns to 'verbs' or 'adjectives' to express their relations of time, status, methods and causes." Li Fengyi (1984) pointed out that prepositions are attached to the noun, pronoun or nouns and verb phrases in front of them. They are combined with these words or phrases respectively to form a prepositional structure, which indicates the subject, object, time location, direction or purpose of action behavior.

\subsection{Some Grammatical Features Cannot be Justified}

Grammatical features of prepositions are described more comprehensively by the following: Zhang Zhigong, Li Jinxi, and Zhao Yuan Ren. To summarize, prepositions have the following grammatical features:

Usually cannot say that alone cannot act as a subject, predicate and other part of the sentence.

Like:

我们对于这个问题有不同看法。—×我们对于这个问题。

wǒ mén duì yú zhè gè wèn tí yǒu bù tóng kàn fă

We have different opinions on this issue.—— $\_$We have different opinion this issue.

你从明天开始到这儿来工作。——你从明天。

nǐ cóng míng tiān kāi shǐ dào zhè ér lái gōng zuò

You start working here from tomorrow. —— You from tomorrow.

Then how to explain the following sentences? Like:

你在图书馆学习吗?

nǐ zài tú shū guăn xué xí má

_-Are you studying in the library?

一在。

zài

Yes, I am.

老王从什么时候开始学习法语的?

lăo wáng cóng shí me shí hòu kāi shǐ xué xí fă yǔ dí

When did Laowang begin to learn French?

一五岁。/ 从五岁。

wǔ suì / cóng wǔ suì 
_Five years old/ from five years old.

他到底对谁有意见?

tā dào dǐ duì shuí yǒu yì jiàn

Who does he have opinion on?

一老王/对老王。

- Laowang / On Laowang.

In the example sentences, the preposition "在" can answer the questions individually, and the prepositional phrases "from the age of five" and "On Laowang" formed by the prepositions can also separately answer the questions. There are many other examples of answering the questions alone or in the form of prepositional phrases so that they do not deny the existence of this phenomenon.

Not as the predicate center, that prepositions are often not as the main verb;

你为谁呐? 我谁也不为。

nǐ wéi shuí nà ? wǒ shuí yě bù wéi 。

Who are you working for? For nobody.

为(wéi) is rarely used like this.

- Chinese Grammar

It is not uncommon to find that many of the prepositions in the definition of traditional grammar play a predicate role in sentences without a core predicate verb and often make the main verb, as in the following example:

老跟着人就不能独立了。

lăo gēn zhē bié rén jiù bù néng dú lì liăo

You can not be independent if always following others

王先生不在。

wáng xiān shēng bù zài

Mr. Wang is not here.

春天到了。我预备六点到家。

chūn tiān dào liăo 。 wǒ yù bèi liù diăn dào jiā 。

Spring is coming. I am going home at six.

你上我这（来）。

nǐ shàng wǒ zhè ( lái )

You come to my house.

赶不上这趟火车。

găn bù shàng zhè tàng huǒ chē

Can not pick up this train.

枪口一齐冲着外头。

qiāng kǒu yī qí chōng zhē wài tóu

Muzzle directed at the outside

这窗户朝北。

zhè chuāng hù cháo běi

This window faces north.

The above examples are from Zhao Yuanren's Grammar of Chinese. The “跟(gēn) 、在(zài)、到 (dào) 、上(shàng)、冲(chōng) 、朝(cháo)” these prepositions in the traditional definitions in the example sentence are predicates in the sentence, which can be seen taht Mr. Zhao himself can not justify it.

Prepositions do not have physical characteristics, can not be followed by "着((zhē) " "了(liăo) ", " 过(guò) ", can not overlap.

Let's look at the following examples:

挨(āi) ——挨(āi) 着(zhē) 就(jiù) ——就(jiù) 着(zhē) 对(duì) ——对(duì) 着 zhēe) 离(lí) — 离(lí) 着(zhē) 


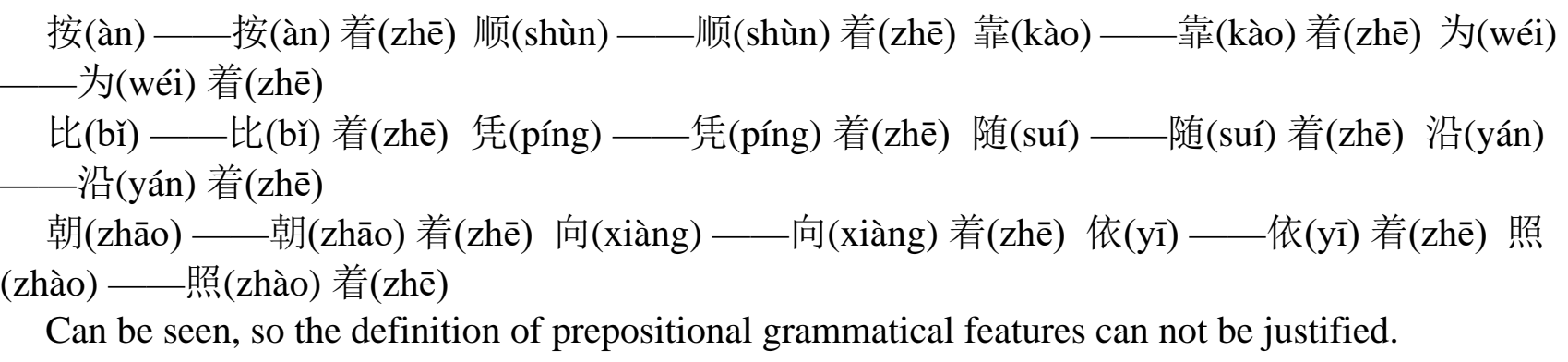

\subsection{Some grammatical functions of the discourse to be more general}

According to Liu Yuehua (2001), prepositions are located in the nouns (phrases), pronouns, and nouns (phrases) and pronouns form prepositional objects. Such as:

1) Noun: 学生对老师很尊敬。The students respect the teacher very much

2) Noun phrase: 老师对我们的学习和生活都很关心。The teacher is very concerned about our study and life

3) Pronoun: 班主任谢老师比我更了解这个学生的情况。Class teacher Xie knows more about this student's situation than me

Is the preposition only in front of noun (phrase), pronoun? We see the followings:

黑嫂爱上老弯, 大概从他不吃救济粮开始。

Hei Shao fell in love with Lao Wan, probably from the beginning he did not eat relief food.

晚霞由橘红渐渐变成暗红。

The sunset turns from orange to dark red

老人骑车, 慢一点比快一点好。

It is better for the elderly ride a little slower than a little faster.

Visible, the preposition can also be located in the sentence, adjective (phrase) before.

To sum up, according to the traditional definitions listed above, the grammar either defines the preposition by simply introducing the position of the preposition in the sentence, or enumerates a limited number of words as prepositions by enumeration, or simply asserts that the prepositional features The description can only be a general description of the boundaries, not strict and absolute definition. In this way, such a definition is very vague for Chinese learners, especially learners of Chinese as a foreign language.

In this regard, from the perspective of structural transformation grammar to re-prepositions.

\section{A New Definition of Chinese Prepositions by Structure Transformation Grammar}

According to the structure-switching grammar, "any construction of a language is composed of at least two components, the relationship between the two components of each other, the relationship between the central language and the dependent language, or the two relations are different Relation. As for a sentence, as long as the first judge the relationship between the basic components, we can know what is in the sentence as a predicate component. Therefore, from the perspective of the structure of the conversion of grammatical Chinese prepositions are defined as follows.

Prepositions are words that can not serve as predicates but that can guide nominal components, or predicates (phrases), adjectives (phrases), and sentences that are equivalent to nominal components. Such as:

To guide the nominal composition:

咱们沿着湖边散步吧。

zán mén yán zhē hú biān sàn bù bā

Let's walk along the lake.

被他揍了一顿。

bèi tā zòu liăo yī dùn

Beat by him.

To guide predicates (phrases) equivalent to nominal components: 
从完成毕业论文看, 这个班的整体素质是不错的。

cóng wán chéng bì yè lùn wén kàn, zhè gè bān dí zhěng tǐ sù zhì shì bù cuò dí

From the completion of the thesis, the overall quality of this class is not bad.

According to the structure conversion grammar's definition of prepositions, we can completely exclude the special prepositions that have been mentioned in the sentence under the definition of traditional grammar. Such as:

A:我不拿他的东西。（predication function）I do not take his stuff

$\mathrm{B}$ :我不拿领导的话压你。I do not take the leadership’s words to stress you

A:我家门口对着一棵老槐树。（predication function）There is an old locust tree opposite to my doorstep

B:我们对他不怎么友好。We are not very friendly to him

The sentence $\mathrm{A}$ in the above example, based on the structure conversion grammar, the “拿 (ná)”, “跟(gēn)”, “对(duì)” play predication function in the sentence, which are completely different from sentence $B$.

Thus, we separate the prepositions which, under the traditional definition of the above examples, serve as predicates, as a class of prepositions, to be discussed in detail later.

\section{Classification of prepositions}

4.1 According to the object is located before or after the introduction is divided into: preposition, postpositional preposition, both preposition and postpositional preposition.

a. Prepositions: Prepositions can only be located in front of the objects they are referred to. Most prepositions belong to prepositions such as 由(yóu), 自(zì), 自(zì) 从(cóng), 打(dă), 对(duì), 于(yú), 关(guān) 于(yú), 除(chú) 了(liăo), 按(àn) 照(zhào), 按(àn), 照(zhào), 把(bă), 被(bèi), 于(yú), 沿(yán)

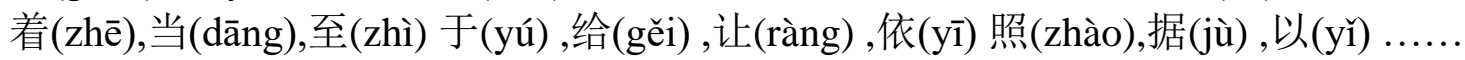

Example:

对于具体问题要进行具体分析。

duì yú jù tǐ wèn tí yào jìn xíng jù tǐ fēn xī

For specific issues, it needs specific analysis

他已决定报考北大, 至于学什么专业, 还没定下来。

tā yǐ jué dìng bào kăo běi dà , zhì yú xué shí me zhuān yè , huán méi dìng xià lái.

He has decided to apply Peking University, as to what majors, have not set them down

In the above example sentences, "对(duì) 于(yú) " and "至(zhì) 于(yú) " are located in front of the "具(jù) 体(tî) 问(wèn) 题(tí) " and "学(xué) 什(shí) 么(me) 专(zhuān) 业(yè) " of the objects to be quoted, respectively, and are prepositions.

b. Postpositional preposition: The preposition located behind the object to which it refers.

Example:

庙里住着一位老和尚。

miào lǐ zhù zhē yī wèi lăo hé shàng

An old monk lives in the temple

山中驻进了游击队。

shān zhōng zhù jìn liăo yóu jī duì

The guerrillas stationed in the mountain.

道旁立着一棵木棉树。

dào páng lì zhē yī kē mù mián shù

A kapok tree stands next to the road.

5 年来，他没有一天不思念自己的祖国。

5 nián lái , tā méi yǒu yī tiān bù sī niàn zì jǐ dí zǔ guó

For five years, he has been missing his own country every day. 
一周以内办好手续。

yī zhōu yǐ nèi bàn hăo shǒu xù

The procedures is completed within one week.

The "里(lî) ", "中(zhōng) ", "旁(páng) ", "来(lái) " and "以(y̌̃) 内(nèi) " refer to the quoted objects "庙(miào) ", "山(shān) ", "道(dào) ", "5 年(nián) " , "一(ȳi) 周(zhōu) ", which is a postpositional preposition.

c. Prepositions for both prepositions and postpositional:

Example:

花猫跳上餐桌。

huā māo tiào shàng cān zhuō

A cat jumps onto the table.

树上挂满了沉甸甸的果实。

shù shàng guà măn liăo chén diàn diàn dí guǒ shí

Heavy fruit hang on the tree.

The preposition "上(shàng) " may precede the "餐(cān) 桌(zhuō) " of the object it is referring to, and may also be located after the "树(shù) " of the object it is referring to, which may be either prepositional or postpositional.

\subsection{Classification according to prepositions of the composition}

a. Single word preposition: A preposition consisting of a single word

b. Phrase preposition: A preposition consisting of two words (one of which must be a preposition)

\section{Classification preposition predicate}

\subsection{Press before or after the object being referred}

a. Prepositional predicate

她家对着一条大马路。

tā jiā duì zhē yī tiáo dà mă lù

Her home is opposite a big road

老跟着别人就不能独立了。

lăo gēn zhē bié rén jiù bù néng dú lì liăo

You can not be independent if always following others.

一个往东, 一个往西。

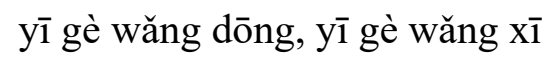

One towards east, one towards west

她在家。

tā zài jiā

She is at home

b. Post-referral predicate

警戒线之下。

jǐng jiè xiàn zhī xià

Under the cordon.

权限范围之内。

quán xiàn fàn wéi zhī nèi

Within the limits of authority.

新中国成立之后。

xīn zhōng guó chéng lì zhī hòu

After the founding of new China

吃早饭之前。

chī zăo fàn zhī qián 
Before eating breakfast

\subsection{According to the constituent elements of the predicate}

a. Words refer to predicates: the predicate composed of a single word.

She is at home. 在、对、跟、为、为了、替、朝、向、往、到、依、凭...

zài 、 duì 、 gēn 、 wéi 、 wéi liăo 、 tì 、 zhāo 、 xiàng 、 wăng 、 dào 、 ȳî 、 píng ...

b. Phrase predicate: the predicate composed of two words (one of which must be a predicate).

从...到, 在...里, 在...中, 在..内 $($ 之内 $)$, 在...以上, 在...之上, 在...之下, 在...之 内, 在...之外, 在...之前, 在...之后

cóng ... dào, zài ... lî̀, zài ... zhōng, zài .. nèi ( zhī nèi ) , zài ... yǔ shàng, zài ... zhī shàng, zài ... zhī xià , zài ... zhī nèi , zài ... zhī wài , zài ... zhī qián, zài ... zhī hòu

北京的工业从无到有。

běi jīng dí gōng yè cóng wú dào yǒu

Beijing's industry develops from nothing

水仙花在水中。

shuǐ xiān huā zài shuǐ zhōng

Daffodils are in the water

她在家里。

tā zài jiā lǐ

\section{Conclusion}

Prepositions, which have some of the functions under the traditional grammar definition, are separately listed as a new part of speech for research. The establishment of this new word class solves the long-term confusion in the traditional grammar about the nature of prepositions, the types of activities involved and the prepositional utilization. Naturally, with this new word category, the vagueness of prepositions and verbs has been resolved. The nature of prepositions is further defined.

\section{Acknowledgement}

This article was completed under the guidance of Prof. Chen Guohua, China Foreign Language Education Research Center, Beijing Foreign Studies University and belongs to Professor Chen's "Teaching Chinese as a Foreign Language" achievement. This article is a scientific research which belongs to the Inner Mongolia Department of Education humanities and social science project "based on 'school-enterprise cooperation' business English professionals training programs" (subject number: NJSY388).

\section{References}

[1] Chen Changlai (2002), Prepositions and Introductory Functions. Hefei: Anhui Education Press.

[2] Chen Guohua (to be Published), College English Teaching Method. Beijing Foreign Studies University Chinese Foreign Language Education Research Center.

[3] Guo Yi Zhou (1984), Adverbs, Prepositions, Conjunctions. Shanghai: Shanghai Education Press.

[4] Guo Yi Zhou (1984), Chinese Knowledge Speech. Shanghai: Shanghai Education Press.

[5] Li Jinxi (1924, 1992), New Chinese Grammar. Beijing: Commercial Press.

[6] Li Feng Yi (1985), Modern Chinese Function Words to Make Sentences. Beijing: Guangming Daily Press.

[7] Liu Danqing (2002), Box Prepositions in Chinese, Contemporary Linguistics, 2 (4), 241-253.

[8] Liu Yuehua (2001), Practical Modern Chinese. Beijing: Commercial Press. 
[9] Lu Shuxiang (1984), Chinese Grammar Strategic. Beijing: Commercial Press.

[10] Lu Shuxiang, Zhu Dexi (1952), Grammatical Rhetoric. Beijing: China Youth Press.

[11] Ma Jianzhong (1983), Ma Shi Wen Tong. Beijing: Commercial Press.

[12] Shang Ping (2005), "Preposition +" Phenomenon Investigation, Linguistic Applications 9.

[13] Wang Li (1985), Chinese Modern Grammar. Beijing: Commercial Press.

[14] Zhang Zhigong (1953), Chinese Grammar Common Sense. Beijing: China Youth Press.

[15] Zhao Yuanren (1968/1980), A Grammar of Spoken Chinese, Ding Bang's new translation. Hong Kong: Chinese University of Hong Kong Press.

[16] Zhou Gang (2002), Conjunctions and Related Issues. Hefei: Anhui Education Press

[17] Zhou Xiaobing (1997), Grammatical Properties of Prepositions and Systematic Approach to Preposition Study, Journal of Sun Yat-sen University, 3.

[18] Zhu Dexi (1982), Grammar Notes. Beijing: Commercial Printing Museum. 